REFERENCES

Auerbach, V. H., Digeorge, A. M., and Carpenter, G. C. (1967). In Amino Acid Metabolism and Genetic Variation, edited by W. L. Nyhan. New York, McGraw Hill.

Barber, G. W., and Spaeth, G. L. (1967). Lancet, 1, 337.

Boivin, P., and Galand, C. (1967). Revue Française d'Études Cliniques et Biologiques, 12, 372.

Fisher, R. A. (1930). The Genetical Theory of Natural Selection. Clarendon Press, Oxford.

Garrod, A. E. (1909). Inborn Errors of Metabolism. London, Oxford University Press.

Harris, H. (1969). British Medical Bulletin, 25, 5.

Justice, P., O'Flynn, M. E., and Hsia, D. Y. Y. (1967). Lancet, 1, 928.

Kelley, W. N. (1968). Federation Proceedings, 27, 1047.

Kelley, W. N., Rosenbloom, F. M., Henderson, J. F., and Seegmiller, J. E. (1967). Proceedings of the National Academy of Sciences of the United States of America, 57, 1735.

Laberge, C. (1969). American fournal of Human Genetics, 21, 36.

La Du, B. N., Zannoni, V. G., Laster, L., and Seegmiller, J. E. (1958). Fournal of Biological Chemistry, 230, 251

Lehmann, H., and Carrell, R. W. (1969). British Medical Bulletin, 25, 14.
Lesch, M., and Nyhan, W. L. (1964). American fournal of Medicine, 36, 561 .

Livingstone, F. B. (1969). American fournal of Physical Anthropology, 30, 55.

Morrow, G., Barness, L. A., Cardinale, G. J., Abeles, R. H., and Flaks, I. G. (1969). Proceedings of the National Academy of Sciences of the United States of America, 63, 191.

Oberholzer, V. G., Levin, B., Burgess, E. A., and Young, W. F. (1967) Archives of Disease in Childhood, $42,492$.

Paglia, D. E., et al. (1968). Fournal of Clinical Investigation, 47, 1929.

Perry, T. L. (1967). In Amino Acid Metabolism and Genetic Variation, edited by W. L. Nyhan. New York, McGraw-Hill.

Perutz, M. F., and Lehmann, H. (1968). Nature, 219, 902.

Piomelli, S., Corash, L. M., Davenport, D. D., Miraglia, J., and Ambrosi, E. L. (1968). Fournal of Clinical Investigation, 47, 940 .

Rosenberg, L. E., Lilljeqvist, A.-C., and Hsia, Y. E. (1968). New England fournal of Medicine, 278, 1319.

Seegmiller, J. E., Rosenbloom, F. M., and Kelley, W. N. (1967). Science, $155,1682$.

Tedesco, T. A., and Mellman, W. J. (1967). Proceedings of the National Academy of Sciences of the United States of America, 57, 829 .

Woolf, L. I., Cranston, W. I., and Goodwin, B. L. (1967). Nature, 213, 882.
.
hida,

Yoshida, A., Stamatoyannopoulos, G., and Motulsky, A. G. (1967). Science, $155,97$.

\title{
Speculation on Pathogenesis in Death from Respiratory Syncytial Virus Infection
}

\author{
P. S. GARDNER,* M.D., DIP.BACT. ; J. MCQUILLIN,† B.SC., F.I.M.L.T. ; S. D. M. COURT, ‡ M.D., F.R.C.P.
}

British Medical fournal, 1970, 1, 327-330

$\mathrm{S}_{\mathrm{c}}^{\mathrm{u}}$ mmary: The lungs of three infants, two with bronchiolitis and one with pneumonia, were examined by fluorescent antibody techniques for the distribution of respiratory syncytial (R.S.) virus, and also for the presence of human globulin. In bronchiolitis the lungs contained little virus, whereas in pneumonia virus was abundant and widespread; and, paradoxically, while in bronchiolitis human globulin had the same scanty distribution as virus it was absent in pneumonia. It is suggested that the essential process in bronchiolitis is a widespread type 1 allergic reaction dependent on a second encounter with R.S. virus antigen, whereas in R.S. virus pneumonia the mucosal necrosis and alveolar and interstitial inflammation are the result of direct virus damage to the lungs. The alternative explanation put forward is that the process may be a type 3 allergic reaction.

\section{Introduction}

For the past 10 years we have been studying the role of respiratory syncytial (R.S.) virus in acute respiratory infections of children (Gardner et al., 1960; Andrews and Gardner, 1963; Elderkin et al., 1965; Holdaway et al., 1967; Gardner, 1968), and a recent study of 22 deaths, in which four cases of pneumonia and five of bronchiolitis could be attributed to this virus, has emphasized our uncertainty regarding the precise processes involved (Aherne et al., 1970).

Three problems particularly concern us. (1) Why does $80^{\prime \prime}$, of acute bronchiolitis, almost entirely due to R.S. virus, occur in the first six months of life when maternal antibody is still present? (Newcastle upon Tyne Respiratory Survey 1969). (2) Why, in infants vaccinated against R.S. virus, did subsequent infection with naturally occurring virus produce illnesses of greater severity than in those not vaccinated? (Chin et al., 1969; Fulginiti et al., 1969; Kapikian et al., 1969; Kim et al., 1969a).(3) Is the pathogenesis in fatal bronchiolitis and fatal pneumonia due to R.S. virus the same or different? If it differs, what criteria of differentiation can be accepted?

\footnotetext{
* Consultant Virologist and Honorary Reader.

$\ddagger$ Professor of Child Health, Royal Victoria Infirmary and University of Newcastle-upon-Tyne, Newcastle-upon-Tyne 1.
}

We are attempting to answer these questions by bringing forward additional, though still incomplete, evidence of the cell-virus relationship in bronchiolitis and pneumonia caused by R.S. virus, derived from the immunofluorescent study of the lungs of three children who died.

\section{Materials and Methods}

\section{Virus Techniques}

Since the validity of our observations and deductions depends on the methods employed, these are described in some detail.

(a) Preparation of Inoculum for Virus Isolation.-Lung material from each case was processed by methods already described (Gardner et al., 1967; Aherne et al., 1970).

(b) Preparation of Impression Smears.-On arrival in the laboratory the post-mortem lung material was promptly stored at $4^{\circ} \mathrm{C}$. until ready for processing. Within 30 minutes of reception two small pieces of tissue, about $2 \mathrm{~mm}$. sq. by $1 \mathrm{~mm}$. thick were removed from the lung and placed about lin. $(2.5 \mathrm{~cm}$.) apart on a glass slide. A series of impression smears were made from the two pieces of tissue by pressing a succession of glass slides on top of them. Six to eight slides could be prepared in this way before the tissue was completely used. The smears were then allowed to dry in air and fixed in acetone at $4^{\circ} \mathrm{C}$. for 10 minutes. They were stained by the technique already described, and controls for specificity and efficiency of techniques were included (Gardner and McQuillin, 1968; McQuillin and Gardner, 1968). For obvious reasons negative controls could not be tested, but since many lungs which were negative on culture and also lungs infected with viruses other than R.S. virus were examined in this way and gave no fluorescence with R.S. virus antiserum, specificity of the R.S. virus antiserum for R.S. virus antigen in lung tissue could be accepted.

(c) Preparation of Frozen Sections.-At the same time as the pieces for impression smears were cut from the lung two pieces about 3-4 $\mathrm{mm}$. sq. and 1-2 $\mathrm{mm}$. thick were cut and placed in bijou bottles. These pieces were snap-frozen on to the side of the bottle in a dry ice and alcohol mixture for storage at $-70^{\circ} \mathrm{C}$. until required. Cryostat sections were cut and a series of single sections were placed on clean glass slides; the sections were fixed in acetone at $4^{\circ} \mathrm{C}$. for 20 minutes. The staining procedures have been described elsewhere, two sections being treated with R.S. virus 
antiserum and two sections with normal rabbit serum acting as controls. In the last stage, after the final rinse of the section in distilled water, the material was dehydrated and mounted in Gurr's UVinert mountant.

(d) Staining of Impression Smears with Antihuman Globulin.- Two smears of each of the two pieces of lung were stained in parallel, one with normal rabbit serum followed by fluoresceinlabelled antihuman globulin and the other with R.S. virus rabbit antiserum and fluorescein-labelled anti-rabbit globulin. Both conjugates contained naphthalene black as a counterstain and were supplied by Winthrops Biologicals Limited. The smears stained with R.S. virus rabbit antiserum and anti-rabbit globulin indicated the distribution of R.S. virus antigen and the smears stained with normal rabbit serum and antihuman globulin indicated the distribution of human globulin in the two pieces of lung tissue. The antihuman globulin was a crude preparation, probably containing antibodies against all globulin fractions.

Previous to use of antihuman globulin in the above test, control tests were carried out to establish its efficacy in locating human antibody. Nasopharyngeal secretions known to contain R.S.-virusinfected cells, R.S.-virus-infected HEp2 cells, and negative HEp2 cells were treated with high-titre human convalescent antisera against R.S. virus and then with labelled antihuman globulin. Parallel tests, using R.S. virus rabbit antiserum and antirabbit globulin against duplicate preparations were carried out with normal serum controls included. It was found that human serum with antihuman globulin gave fluorescence identical with that produced by rabbit antiserum and antirabbit globulin against R.S. virus antigen in both positive nasopharyngeal secretions and tissue culture cells. Non-specific fluorescence was not found in any of the controls with negative cells or normal sera.

(e) Complement Fixation Tests on Lung Extracts.-Snap frozen pieces of lung tissue were quickly thawed and two small pieces were cut and used for impression smears. These were then stained by the indirect fluorescent antibody technique to ensure that the R.S. virus antigen was still present. The remainder of the tissue was weighed and suspended in sufficient veronal buffer to give a dilution (wet weight/volume). The tissues were homogenized in the veronal buffer and the suspension was centrifuged at 3,000 r.p.m. for 10 minutes at $4^{\circ} \mathrm{C}$. The supernatant was used as antigen in a complement fixation test, a microtechnique based on the method of Bradstreet and Taylor (1962) being employed.

\section{Clinical Features}

The clinical features of the three illnesses were as follows:

Case. 1-This infant aged 3 months collapsed suddenly and was dead on reaching hospital. There had been a mild upper respiratory infection for the previous five days.

Case 2.-After five days of "cold," this 3-month-old infant became severely ill with the clinical picture of bronchiolitis and died within two hours. His twin brother had a similar illness at the same time, but recovered.

Case 3.-This infant was admitted to hospital at 3 weeks of age with suspected pneumonia and, in spite of treatment, died on the fifth day of the illness.

\section{Pulmonary Histology}

The detailed histology of infants with bronchiolitis and pneumonia, including Cases 1 and 3 has been previously described (Aherne et al., 1970). We felt, however, that it was necessary to illustrate the pulmonary histology in the three deaths which are the basis of this paper.

Fig. 1 illustrates the histology in the lungs of Cases 1 and 2. It shows an acute bronchiolitis with inflammation mainly affecting bronchioles between 300 and $75 \mu$ in size. There is necrosis of epithelium, peribronchiolar infiltration with lymphocytes, mucous secretion is increased, and thick plugs of cell debris and fibrin are present in the bronchioles. By contrast, though there is some enlargement of the alveoli, there is no cellular infiltration. Fig. 2 illustrates the histology of the lung from Case 3. It shows an acute virus pneumonia, with an inflammatory exudate of mononuclear cells mainly in the alveoli, small bronchioles, and alveolar ducts, and with inflammatory change also in the interstitial tissue.

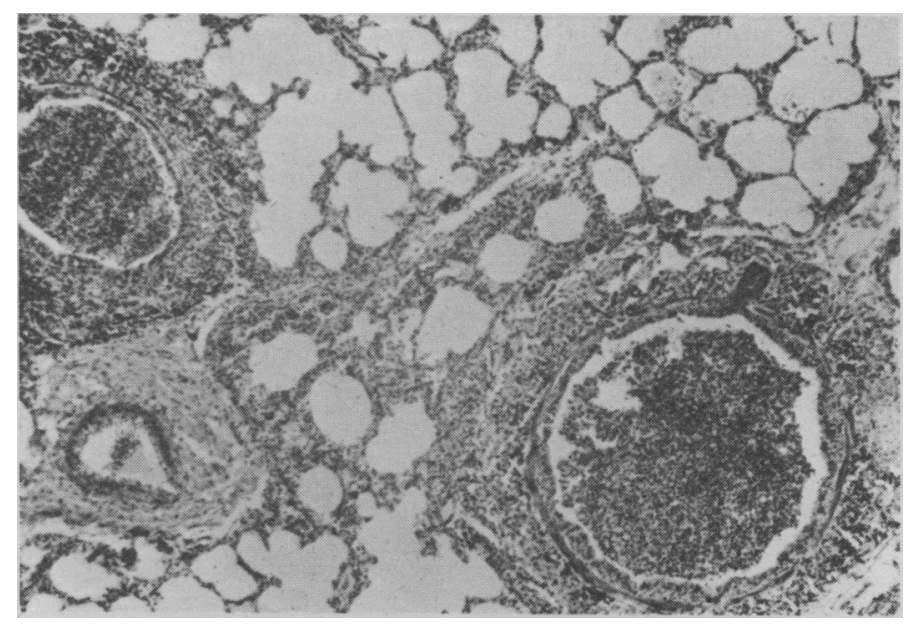

Fig. 1.-Acute bronchiolitis, histology of lungs of Cases 1 and 2. (x 128.) (By courtesy of Dr. W. A. Aherne.)

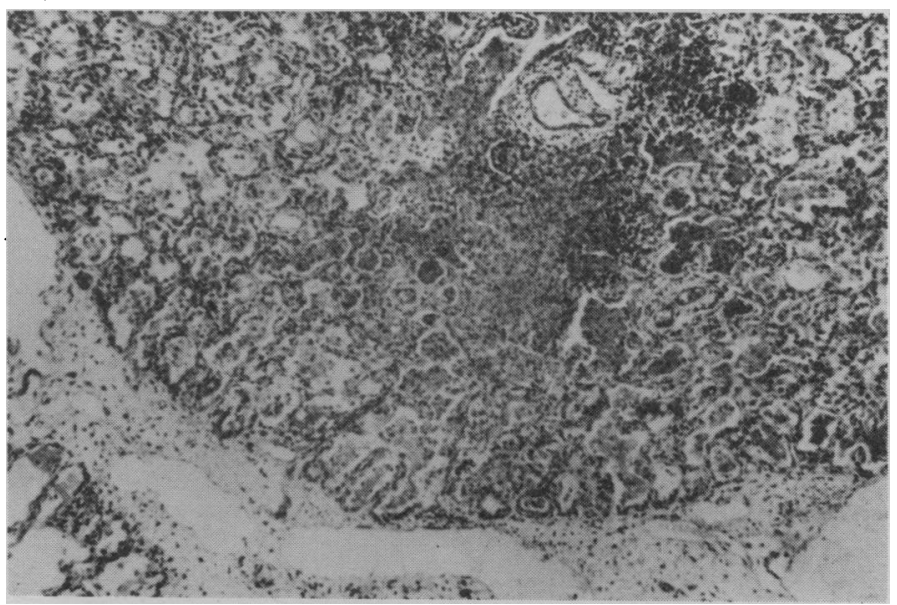

FIG. 2.-Acute virus pneumonia, histology of lung of Case 3. (x 160.) (By courtesy of Dr. W. A. Aherne.)

\section{Distribution of R.S. Virus}

Isolation of R.S. Virus.-Virus was isolated from the lungs of one infant with bronchiolitis but not the other, and specimens were not available from either before death. Virus was isolated from the child with pneumonia both from nasopharyngeal secretion before death and from the lungs and bronchial secretions after death.

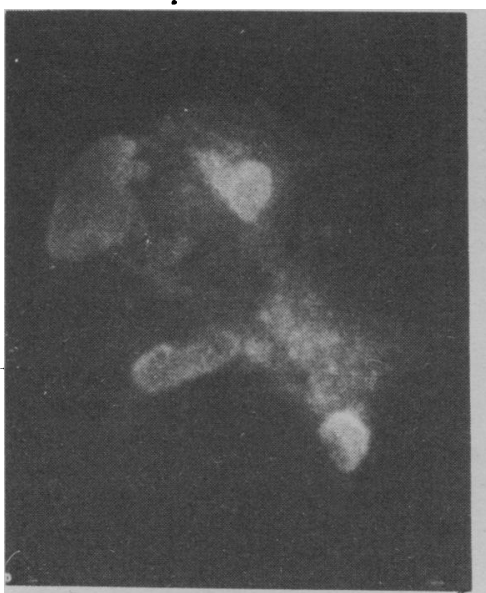

FIG. 3

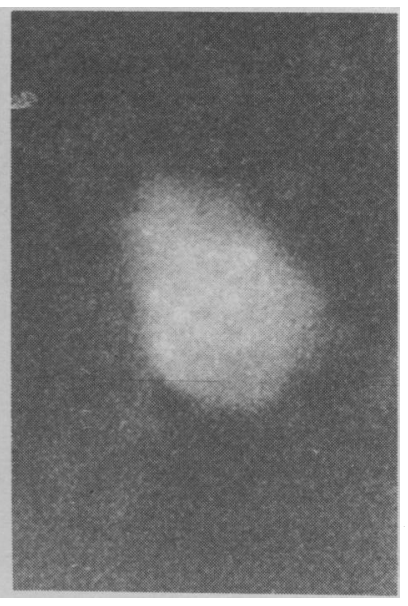

FIG. 4
FIG. 3.-R.S. virus-infected cells in impression smear of lung of Case 1 stained by the indirect fluorescent antibody technique. (x 2,500.) FIG. 4.R. S., virus-infected cell in impression smear of lung of Cases 2 stained by the indirect fluorescent antibody technique. $(x 4,000$.) 


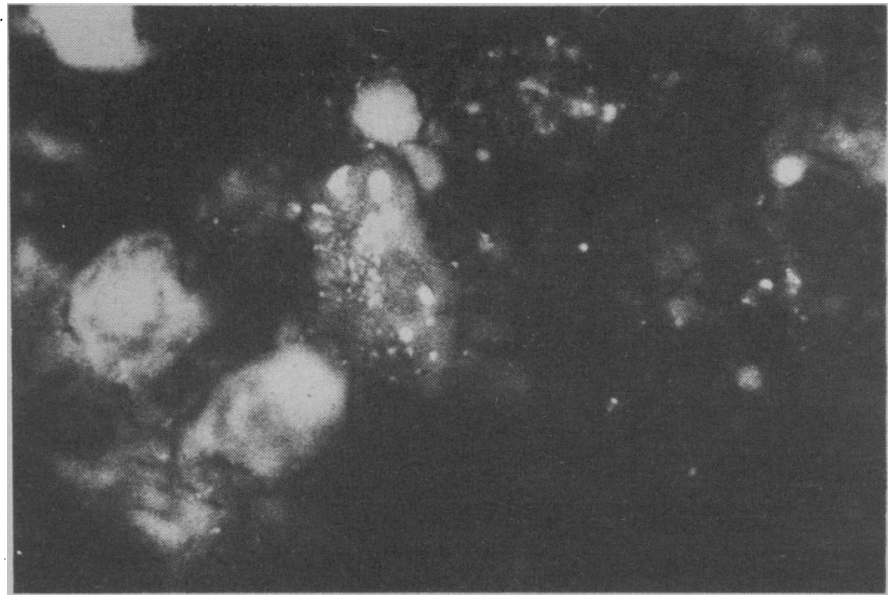

FiG. 5.-R.S. virus infected cells in impression smear of lung of Case 3 stained by the indirect fluorescent antibody technique. $(x 1,200$.)

Fluorescent Antibody Investigation of Impression Smears of Lung.-Impression smears of the three lungs were stained by the indirect fluorescent antibody technique for R.S. virus. Figs. 3 and 4 show the lungs of Cases 1 and 2, who had bronchiolitis. Virus-infected cells are extremely scanty in distribution. Fig. 5 shows the lung of Case 3 with pneumonia, and here, by contrast, virus-infected cells are abundant throughout the lung. To determine whether human globulin was present in these lungs, parallel impression smears were stained with antihuman globulin. Figs. 6 and 7 show impression smears of lungs of both infants with bronchiolitis stained in this way. There is a remarkable similarity between Figs. 3 and 6 and Figs. 4 and 7. This was not an isolated finding; many impression smears were made from the lungs of these two infants, and all showed the same scanty distribution of virus-infected cells and cells stained with antihuman globulin. This contrasted sharply with pneumonia, where the impression smears contained an abundance of virus but no human globulin at all (Fig. 8).

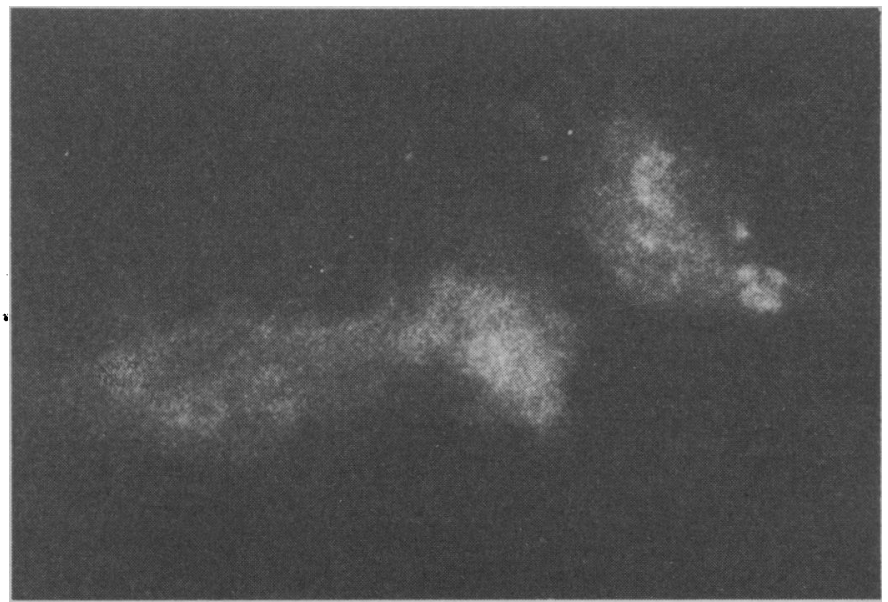

FIG. 6.-Human globulin in impression smear of lung of Case 1 stained by the indirect fluorescent antibody technique. (x 2.875.)

Fluorescent Antibody Investigations of Frozen Sections of Lung.-These confirmed the appearances seen on the impression smears; they are not illustrated since the quality of the sections did not lend itself to good photography.

Complement Fixation Tests.-On repeated testing we found negative complement fixation with R.S. antiserum in the lungs of the infants with bronchiolitis and positive complement fixation in the lungs of the infant with pneumonia.

These findings are summarized in the Table.
Summary of Findings in the Three Children

\begin{tabular}{|c|c|c|c|c|c|c|}
\hline $\begin{array}{l}\text { Case } \\
\text { No. }\end{array}$ & $\begin{array}{c}\text { Clinical } \\
\text { Diagnosis }\end{array}$ & Histology & $\begin{array}{c}\text { Fluorescent } \\
\text { Antibody } \\
\text { Staining } \\
\text { for R.S. } \\
\text { Virus }\end{array}$ & $\begin{array}{c}\text { Fluorescent } \\
\text { Staining } \\
\text { for Anti- } \\
\text { human } \\
\text { Globulin }\end{array}$ & $\begin{array}{c}\text { R.S. } \\
\text { Viruses } \\
\text { Isolated }\end{array}$ & $\begin{array}{c}\text { Comple- } \\
\text { ment } \\
\text { Fixation } \\
\text { Test for } \\
\text { R.S. Virus } \\
\text { Antigen }\end{array}$ \\
\hline $\begin{array}{l}1 \\
2 \\
3\end{array}$ & $\begin{array}{l}\text { Bronchiolitis } \\
\text { Bronchiolitis } \\
\text { Pneumonia }\end{array}$ & $\begin{array}{l}\text { Bronchiolitis } \\
\text { Bronchiolitis } \\
\text { Pneumonia }\end{array}$ & $\stackrel{+}{+}++$ & $\begin{array}{l}+ \\
+ \\
+\end{array}$ & $\frac{t}{t+}$ & $\begin{array}{r}<1 / 4 \\
<1 / 4 \\
1 / 4-1 / 8\end{array}$ \\
\hline
\end{tabular}

R.S.V. Isolation: $-=$ No viruses isolated. $+=$ Low concentration of virus as estimated by time of its appearance on tissue culture. $+++=$ High concentration

Fluorescent Staining: $-=$ Absence of fluorescence. $+=$ Scanty distribution of fuorescence. $++++=$ Widespread distribution of fluorescence.

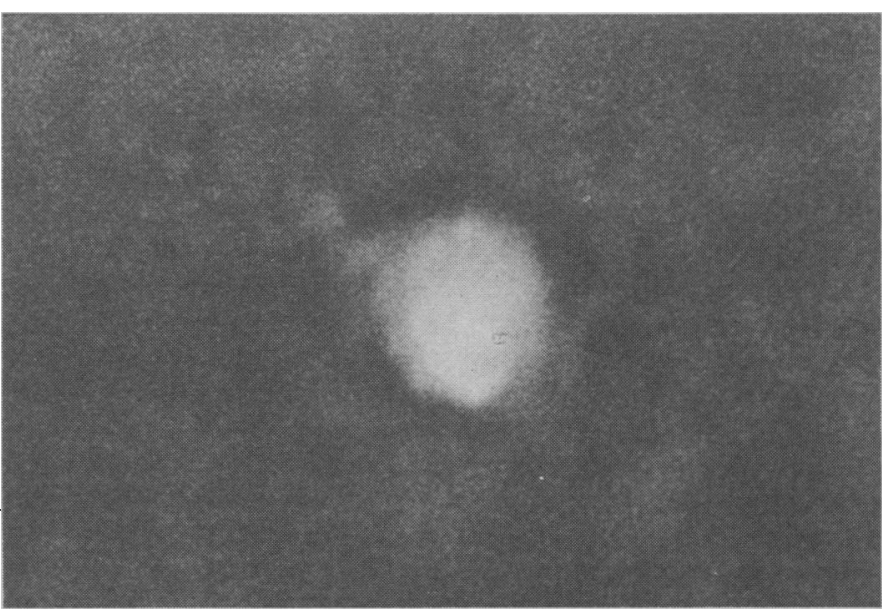

Fig. 7.-Human globulin in impression smear of lung of Case 2 stained by the indirect fluorescent antibody technique. (x 3,750.)

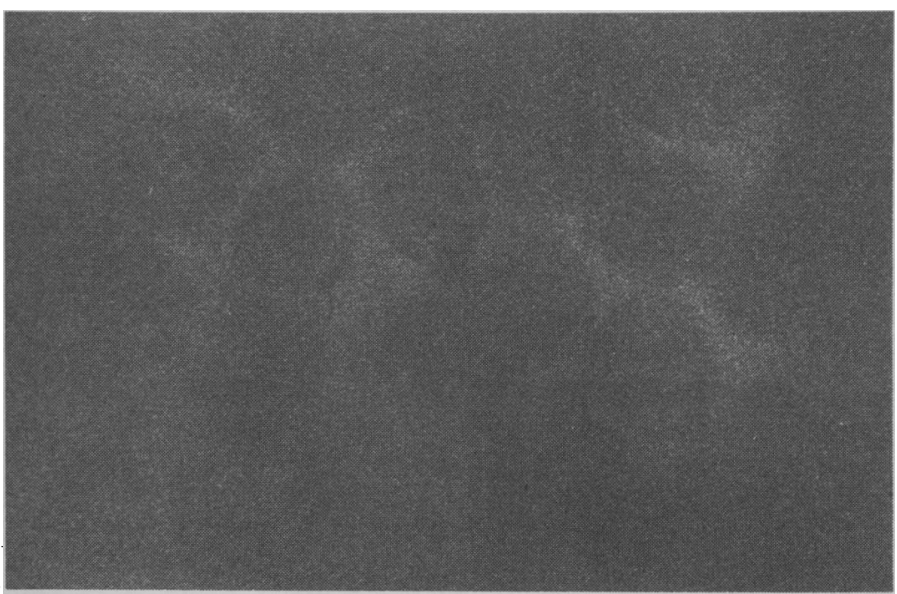

Fig. 8.-Cells of impression smear of lung of Case 3 stained by the indirect fluorescent antibody technique for human globulin. (x 1,500.)

\section{Discussion}

Our observations suggest that in bronchiolitis virus is scanty in amount and patchy in distribution, whereas in pneumonia it is abundant and widespread. Human globulin, on the other hand, shows the same distribution as virus in bronchiolitis but is absent in pneumonia. How far do these facts explain the pathogenesis of these two conditions?

Before attempting an answer we must take into account the experience of certain American workers that, after inoculation with killed vaccine, children later infected naturally with R.S. virus suffered more severe illnesses than unvaccinated children, and some died (Kapikian et al., 1969; Kim et al., 1969a). 
They explained this in terms of a type 3 allergic reaction (Gell and Coombs, 1968), and their views have recently been summarized (Lancet, 1969).

At first sight this is a reasonable hypothesis, a toxic complex being formed between the antibody produced as a result of previous vaccination and the virus antigen from the first naturally occurring infection which follows in the still susceptible child. Both bronchiolitis and deaths from lower respiratory disease due to R.S. virus are explained by a similar sensitivity reaction between excess virus antigen and persisting maternal antibody.

For a type 3 allergic reaction to occur, however, excess of antigen and antibody is necessary. Our observations suggest that antigen is scanty in bronchiolitis and abundant in pneumonia; also, in spite of abundant antigen, human globulin is absent in pneumonia but present in comparable amounts, and with a similar distribution to virus, in bronchiolitis.

If naturally occurring and vaccine-modified R.S. virus bronchiolitis and pneumonia should be attributed to a type 3 reaction, it is possible that the antigen-antibody complexes which damage the bronchiolar lining are soluble and our method of preparing the smears for staining led to their loss. Yet why should loss of antigen occur in bronchiolitis and not in pneumonia when the same methods are used? In an attempt to resolve this, complement fixation tests were performed on fragments of lung from all three infants to find whether virus antigen, either in cells or as a soluble antigenantibody complex, could be detected. In the lungs from bronchiolitis the test was negative, but in pneumonia it was positive at a dilution of $\frac{1}{4}$ with some fixation at a dilution of $\frac{1}{8}$. This is consistent with the different quantity of virus seen by fluorescence in the two diseases.

In our study of respiratory deaths we noted how easily R.S. virus could be isolated from the lungs in pneumonia and how difficult this was in bronchiolitis (Aherne et al., 1970). This is consistent with the scanty amount of virus antigen found in this study in bronchiolitis and its abundance in pneumonia. It would therefore seem that in bronchiolitis, with only a small amount of virus present, there is an early loss of infectivity, even though small patchy foci of antigen can still be detected by fluorescence. We find it difficult on present evidence to accept the view that excess antigen, in the form of a soluble antigen-antibody complex, was lost in staining lung from bronchiolitis but not from pneumonia, and it seems equally improbable that antigen disappeared more quickly after death in bronchiolitis than in pneumonia. Unless abundant antigen and abundant human globulin can be demonstrated in the lungs of infants dying from bronchiolitis it is difficult to see how a type 3 allergic reaction can be the cause of death. A counter-argument at this point could be that the sensitivity of our complement fixation test was too low to detect antigen in the lungs of the children who died of bronchiolitis, or that too little free antigen was available in the "complex" to react.

If a type 3 reaction is not the explanation, what alternatives remain? The evidence pointing to an allergic mechanism in bronchiolitis, though incomplete, is strong, and if this is accepted, then of the three remaining types of allergic response a type 1 is the most likely. This, however, would require a primary sensitizing and secondary reacting encounter to produce clinical bronchiolitis. In view of the ubiquitous nature of R.S. virus, it is mathematically possible for infants, even below the age of 3 months, to have experienced two infections with this virus. If this did occur, the first infection might sensitize by producing a reagin and little immunity, and then the second could be followed by a type 1 reaction. This would take place most readily between 3 and 4 months of age, when the blocking effect of maternal antibody is on the wane. In our experience the highest incidence of bronchiolitis occurs between 2 and 6 months. This hypothesis could also account for the unexpected experience with vaccine. Killed vaccine could produce reaginic as well as neutralizing antibodies, so that a subsequent encounter with the natural virus could, even after a considerable interval, produce a type 1 allergic response.

There is yet another possibility to be considered. We know that protection against respiratory virus infections is provided mainly by IgA produced in the cells of the respiratory mucosa rather than by humoral antibodies. An important element in the pathogenesis of bronchiolitis could therefore be a failure to produce sufficient surface-protecting antibody in the small bronchi and bronchioles. We are investigating this, but at present have no evidence to offer.

To confirm the type 1 hypothesis, however, we must show that two infections can occur in quick succession in the early months of life, and, if they do, show whether protective antibodies in local respiratory secretions develop in the first or second infection. Kim et al. (1969b) reported that a number of infants with acute lower respiratory tract infection due to R.S. virus had high levels of neutralizing activity against R.S. virus in their nasal secretions at the time of admission to hospital. They suggest that "this acute phase neutralizing activity represents antibody which developed early in the course of infection." By our concept of pathogenesis, it could also be explained by a previous infection with R.S. virus. The type 3 hypothesis needs further work to decide whether a soluble antigen-antibody complex exists in the lung.

When we consider R.S. virus pneumonia our evidence suggests that the pathogenesis in the young infant is quite different from bronchiolitis; it represents a primary widespread infection with R.S. virus in the absence of local antibody to inhibit its growth.

The evidence does not allow us to speculate further at present. It is still insufficient to say with certainty that one or other type of allergic reaction does account for severe and fatal bronchiolitis.

It is of the greatest practical importance as well as theoretical interest to decide whether either or both types of allergic reactions are involved in the pathogenesis of severe lower respiratory R.S. virus disease. All workers in this field must be concerned to solve this problem in view of our need to find effective prophylaxis against this highly dangerous virus infection of infancy.

We are indebted to our colleagues, Dr. W. A. Aherne and Dr. W. S. Locke, who supplied the pathological material. We are grateful to the Medical Research Council and the Scientific and Research Subcommittee of the Royal Victoria Infirmary for their continuing support of our respiratory programme.

\section{REFERENCES} Aherne, W.. Bird, T.. Court. S. D. M., Gardner, P. S., and McQuillin,
J. (1970). Fournal of Clinical Pathology. In press.

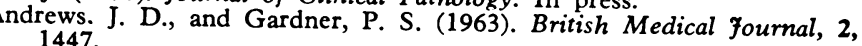

Bradstreet. C. M. P., and Taylor, C. E. D. (1962). Monthly Bulletin of the Ministry of Health and the Public Health Laboratory Service, 21, 96.

Chin, J., Magoffin, R. L., Shearer, L. A., Schieble, J. H., and Lennette, E. H. (1969). American fournal of Epidemiology, 89, 449. Elderkin. F. M.. Gardner, P. S. Turk, D. C., and White, A. C. (1965).
British Medical fournal, 2, 722 .

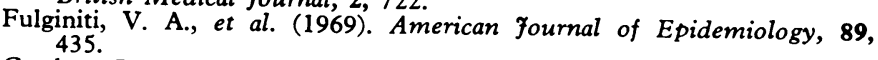

Gardner, P. S. (1968). Archives of Diseases in Childhood, 43, 629.

Gardner, P. S., and McQuillin, J. (1968). British Medical fournal, 3, 340.

Gardner, P. S., et al. (1967). British Medical fournal, 4, 316. Gardner, P. S., Stanfield, J. P., Wright, A. E., Court, S. D. M., and

Gell, P. G. H., and Coombs, R. R. A. (editors) (1968). Clinical Aspects of Immunology, 2nd Ed Blackwell Scientific, Oxford.

Holdaway, D., Romer, A. C., and Gardner, P. S. (1967). Pediatrics, 39, 924.

Kapikian, A. Z., Mitchell, R. H., Chanock, R. M., Shvedoff, R. A., and Stewart, C. E. (1969). American fournal of Epidemiology, 89, A., and

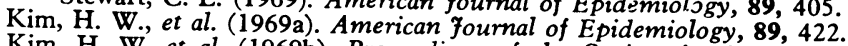

$\mathrm{Kim}, \mathrm{H}$. W. et al. (1969b). Proceedings of the Society for Experimental Biology and Medicine, 131, 658.

Lancet, 1969, 2, 311. McQuillin, J., and Gardner, P. S. (1968). British Medical fournal, 1,
602 . ewcastle upon Tyne Respiratory Survey (1969). Departmental work so
far unpublished. 